Supplement of Geosci. Model Dev., 12, 3283-3310, 2019

https://doi.org/10.5194/gmd-12-3283-2019-supplement

(c) Author(s) 2019. This work is distributed under

the Creative Commons Attribution 4.0 License.

(c) (1)

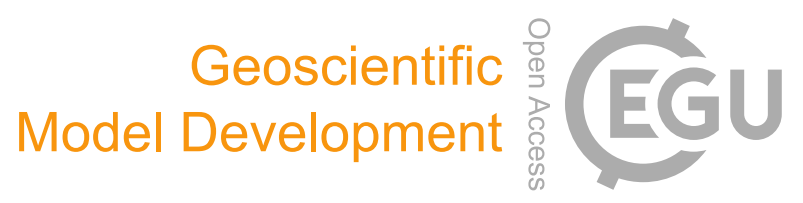

Supplement of

\title{
The FireWork v2.0 air quality forecast system with biomass burning emissions from the Canadian Forest Fire Emissions Prediction System v2.03
}

Jack Chen et al.

Correspondence to: Jack Chen (jack.chen@canada.ca)

The copyright of individual parts of the supplement might differ from the CC BY 4.0 License. 


\section{Supplementary Material}

\section{S1. Reference material}

Table S1. List of acronyms.

\begin{tabular}{|c|c|}
\hline AOD & aerosol optical depth \\
\hline APEI & Air Pollutant Emissions Inventory (Canada) \\
\hline AQ & air quality \\
\hline AQHI & Air Quality Health Index \\
\hline AQS & Air Quality System measurement network (U.S.) \\
\hline AVHRR & Advanced Very High Resolution Radiometer \\
\hline CAM & Canadian Aerosol Module \\
\hline CFB & crown fraction burned \\
\hline $\mathrm{CFC}$ & crown fuel consumption \\
\hline CFFDRS & Canadian Forest Fire Danger Rating System \\
\hline CFFEPS & Canadian Forest Fire Emission Prediction System \\
\hline CFS & Canadian Forest Service \\
\hline CSI & Critical Success Index \\
\hline CTM & chemical transport model \\
\hline CWFIS & Canadian Wildland Fire Information System \\
\hline ECAN & Eastern Canada region \\
\hline ECCC & Environment and Climate Change Canada \\
\hline EPA & Environmental Protection Agency (U.S.) \\
\hline EUSA & Eastern USA region \\
\hline FAR & false alarm rate \\
\hline FBP & Canadian Forest Fire Behavior Prediction System \\
\hline FEPS & Fire Emission Production Simulator (USFS) \\
\hline FFMC & fine fuel moisture code \\
\hline FRP & fire radiative power \\
\hline FWI & Canadian Forest Fire Weather Index System \\
\hline GEM & Global Environmental Multiscale numerical weather prediction model \\
\hline GEM-MACH & Global Environmental Multi-scale Modelling Air quality and Chemistry model \\
\hline GOES & Geostationary Operational Environmental Satellite \\
\hline GTAC & Geospatial Technology and Applications Center \\
\hline HFI & head fire intensity \\
\hline LST & Local Standard Time \\
\hline MB & mean bias \\
\hline MODIS & Moderate Resolution Imaging Spectroradiometer \\
\hline NAPS & National Air Pollution Surveillance network (Canada) \\
\hline NASA & National Aeronautics and Space Administration (U.S.) \\
\hline NEI & National Emissions Inventory (U.S.) \\
\hline NMHC & non-methane hydrocarbon \\
\hline
\end{tabular}




\begin{tabular}{ll} 
NOAA & National Oceanic and Atmospheric Administration (U.S.) \\
\hline NRT & near-real-time \\
\hline NWP & numerical weather prediction \\
\hline NWS & National Weather Service (U.S.) \\
\hline PBL & planetary boundary layer \\
\hline PM & particulate matter \\
\hline POD & probability of detection \\
\hline R & Pearson correlation coefficient \\
\hline RAQDPS & Regional Air Quality Deterministic Prediction System (Canada) \\
\hline RMSE & root-mean-square error \\
\hline ROS & rate of spread \\
\hline SFC & surface fuel consumption \\
\hline TFC & total fuel consumption \\
\hline USFS & United States Forest Service \\
\hline UTC & Coordinated Universal Time \\
\hline VCD & vertical column density \\
\hline VIIRS & Visible Infrared Imaging Radiometer Suite \\
\hline VOC & volatile organic compound \\
\hline WCAN & Western Canada region \\
\hline WUSA & Western USA region \\
\hline &
\end{tabular}


Table S2. Comparison of 2010 and 2017 state- and province-level anthropogenic emissions (tonnes) in western Canada and northwestern U.S.

\begin{tabular}{|c|c|c|c|c|c|c|c|c|c|c|}
\hline & \multicolumn{2}{|c|}{ CO } & \multicolumn{2}{c|}{ NOx } & \multicolumn{2}{c|}{ PM $_{\mathbf{2 . 5}}$} & \multicolumn{2}{c|}{ SO $_{2}$} & \multicolumn{3}{c|}{ VOC } \\
\cline { 2 - 12 } (tonnes) & $\mathbf{2 0 1 0}$ & $\mathbf{2 0 1 7}$ & $\mathbf{2 0 1 0}$ & $\mathbf{2 0 1 7}$ & $\mathbf{2 0 1 0}$ & $\mathbf{2 0 1 7}$ & $\mathbf{2 0 1 0}$ & $\mathbf{2 0 1 7}$ & $\mathbf{2 0 1 0}$ & $\mathbf{2 0 1 7}$ \\
\hline BC+AB Total & $1,976,489$ & $1,749,174$ & $1,013,989$ & 932,227 & 605,857 & 674,816 & 462,687 & 318,534 & 784,144 & 724,425 \\
\hline Relative change & & $-12 \%$ & & $-8 \%$ & & $+11 \%$ & & $-31 \%$ & & $-8 \%$ \\
\hline
\end{tabular}

\begin{tabular}{|c|c|c|c|c|c|c|c|c|c|c|}
\hline \multirow[b]{2}{*}{ (tonnes) } & \multicolumn{2}{|c|}{$\mathrm{CO}$} & \multicolumn{2}{|c|}{ NOx } & \multicolumn{2}{|c|}{$\mathrm{PM}_{2.5}$} & \multicolumn{2}{|c|}{$\mathrm{SO}_{2}$} & \multicolumn{2}{|c|}{ VOC } \\
\hline & 2011 & 2017 & 2011 & 2017 & 2011 & 2017 & 2011 & 2017 & 2011 & 2017 \\
\hline $\begin{array}{r}\mathrm{ID}+\mathrm{MT}+\mathrm{OR}+\mathrm{WA} \\
\text { Total } \\
\end{array}$ & $4,165,074$ & $3,413,646$ & 574,066 & 393,988 & 380,461 & 383,660 & 84,307 & 49,872 & 899,032 & 815,470 \\
\hline Relative change & & $-18 \%$ & & $-31 \%$ & & $+1 \%$ & & $-41 \%$ & & $-9 \%$ \\
\hline
\end{tabular}

5 Table S3. Details of NAPS measurement stations in the Northern-Canada Region (see Figure 1 for a plot of station locations).

\begin{tabular}{lll} 
Station ID & Name and Province/Territory & Latitude, Longitude \\
\hline 000129003 & Yellowknife, NT & $62.452084,-114.364031$ \\
\hline 000129601 & Fort Smith, NT & $60.004486,-111.893377$ \\
\hline 000129203 & Inuvik, NT & $68.35702,-133.7141$ \\
\hline 000080402 & $63-$ 12th Street East, SK & $53.201694,-105.7520$ \\
\hline 000080211 & Saskatoon, SK & $52.13613,-106.66293$ \\
\hline 000080110 & Regina, SK & $50.45017,-104.61722$ \\
\hline 000070203 & Assiniboine College, MB & $49.84225,-99.919$ \\
\hline 000070118 & Winnipeg Pump Station, MB & $49.93229,-97.11327$ \\
\hline 000070119 & Ellen Street, MB & $49.89795,-97.14665$ \\
\hline 000060808 & Thunder Bay, ON & $48.3794,-89.2902$ \\
\hline
\end{tabular}


Table S4. Chemical mass speciation profile for non-methane hydrocarbons (NMHC) for the flaming and smoldering combustion phases for GEM-MACH ADOM-2 mechanism model VOC species (for mechanism details, see Stroud et al., 2008).

\begin{tabular}{|c|c|c|}
\hline Description & $\begin{array}{c}\text { Flaming } \\
\text { Combustion }\end{array}$ & $\begin{array}{c}\text { Smoldering } \\
\text { Combustion }^{2}\end{array}$ \\
\hline $\begin{array}{l}\text { volatile organic carbon (VOC) to total } \\
\text { organic gas (TOG) ratio }\end{array}$ & 1.116755 & 1.0664 \\
\hline$>\mathrm{C} 2$ higher alkenes & 0.082981979 & 0.048898572 \\
\hline$>\mathrm{C} 3$ higher alkanes & 0.061976018 & 0.071567121 \\
\hline higher aldehydes & 0.029332253 & 0.018099495 \\
\hline $\begin{array}{l}\text { multi-substituted aromatics (higher } \\
\text { aromatics) }\end{array}$ & 0.013065163 & 0.006872343 \\
\hline propane & 0.055802877 & 0.024771925 \\
\hline creosol & 0.013031624 & 0.006245644 \\
\hline ethene & 0.03140907 & 0.006480751 \\
\hline formaldehyde & 0.047365044 & 0.008376069 \\
\hline isoprene & 0.00177427 & 0.000410902 \\
\hline methyl-ethyl-ketone & 0.0118993 & 0.008586111 \\
\hline other (non-reactive) & 0.516154304 & 0.627109175 \\
\hline $\begin{array}{l}\text { mono-substituted aromatics (includes } \\
\text { tolueue) }\end{array}$ & 0.038453197 & 0.01630913 \\
\hline Methane (non-reactive in ADOM-2) & 0.08083481 & 0.043683492 \\
\hline Ethane (non-reactive in ADOM-2) & 0.01459366 & 0.011210157 \\
\hline
\end{tabular}

$5{ }^{1}$ mechanism-specific profile for flaming combustion from speciation profile \#95425 in U.S. EPA SPECIATEv4.5

${ }^{2}$ mechanism-specific profile for smoldering combustion from speciation profile \#95428 in U.S. EPA SPECIATEv4.5 
Table S5. Chemical speciation profile for fine ( $\left.\mathbf{P M}_{2.5}\right)$ particulate matter and coarse fraction (PM $\mathbf{P M}_{10.5)}$.

\begin{tabular}{|c|c|c|}
\hline Chemical Component & $\mathbf{P M}_{2.5}$ & PM10-2.5 \\
\hline ammonium & 0.00879149 & 0.00879149 \\
\hline crustal material & 0.0973774 & 0.0973774 \\
\hline elemental carbon & 0.09488849 & 0.09488849 \\
\hline nitrate & 0.001323 & 0.001323 \\
\hline primary organic matter & 0.78500909 & 0.78500909 \\
\hline sulfate & 0.0126105 & 0.0126105 \\
\hline
\end{tabular}


S2. Additional model evaluation material for the 2017 fire season

Table S6. Model performance statistics for daily maximum surface $\mathrm{O}_{3}$ volume mixing ratio (ppbv) for the Aug. 1 to Sept. 18 , 2017 period for measurement stations in the $\mathrm{AB}+\mathrm{BC}$, ID+MT+OR+WA, and Northern-Canada regions.

\begin{tabular}{|c|c|c|c|c|c|c|c|c|c|}
\multicolumn{1}{c|}{} & \multicolumn{3}{c|}{ AB+BC (64 stations) } & \multicolumn{3}{c|}{ ID+MT+OR+WA (25 stations) } & \multicolumn{3}{c|}{ Northern-Canada (10 stations) } \\
\hline Model & RAQDPS & $\begin{array}{c}\text { FW- } \\
\text { Ops }\end{array}$ & $\begin{array}{c}\text { FW- } \\
\text { CFFEPS }\end{array}$ & RAQDPS & $\begin{array}{c}\text { FW- } \\
\text { Ops }\end{array}$ & FW-CFFEPS & RAQDPS & $\begin{array}{c}\text { FW- } \\
\text { Ops }\end{array}$ & FW-CFFEPS \\
\hline count & \multicolumn{3}{|c|}{3131} & \multicolumn{3}{c|}{1220} \\
\hline $\bar{O}$ & \multicolumn{3}{|c|}{41} & \multicolumn{3}{c|}{57} & \multicolumn{3}{c|}{389} \\
\hline $\bar{M}$ & 48 & 71 & 51 & 60 & 90 & 64 & 37 & 41 & 37 \\
\hline $\mathrm{MB}$ & 7 & 30 & 9 & 4 & 33 & 8 & 4 & 9 & 5 \\
\hline $\mathrm{R}$ & 0.55 & 0.37 & 0.55 & 0.70 & 0.36 & 0.67 & 0.73 & 0.61 & 0.71 \\
\hline $\mathrm{RMSE}$ & 19 & 68 & 22 & 18 & 78 & 21 & 9 & 15 & 9 \\
\hline
\end{tabular}

5 Table $\mathrm{S7}_{\text {. O }}$ categorical scores based on a threshold of 65 ppbv for the Aug. 1 to Sept. 18, 2017 period for measurement stations in the $\mathrm{AB}+\mathrm{BC}$, ID+MT+OR+WA, and Northern-Canada regions.

\begin{tabular}{|l|r|r|r|r|r|r|r|r|r|}
\multicolumn{1}{c|}{} & \multicolumn{3}{c|}{ AB+BC } & \multicolumn{3}{c|}{ ID+MT+OR+WA } & \multicolumn{3}{c|}{ Northern-Canada } \\
\hline Model & RAQDPS & $\begin{array}{l}\text { FW- } \\
\text { Ops }\end{array}$ & $\begin{array}{l}\text { FW- } \\
\text { CFFEPS }\end{array}$ & RAQDPS & $\begin{array}{l}\text { FW- } \\
\text { Ops }\end{array}$ & $\begin{array}{l}\text { FW- } \\
\text { CFFEPS }\end{array}$ & RAQDPS & $\begin{array}{l}\text { FW- } \\
\text { Ops }\end{array}$ & $\begin{array}{l}\text { FW- } \\
\text { CFFEPS }\end{array}$ \\
\hline POD & $54 \%$ & $84 \%$ & $67 \%$ & $53 \%$ & $83 \%$ & $65 \%$ & Inf. & Inf. & Inf. \\
\hline FAR & $85 \%$ & $94 \%$ & $88 \%$ & $52 \%$ & $74 \%$ & $58 \%$ & $100 \%$ & $100 \%$ & $100 \%$ \\
\hline CSI & $13 \%$ & $6 \%$ & $11 \%$ & $34 \%$ & $25 \%$ & $34 \%$ & $0 \%$ & $0 \%$ & $0 \%$ \\
\hline
\end{tabular}

Table S8. Model performance statistics for daily maximum surface $\mathrm{NO}_{2}$ volume mixing ratio (ppbv) for the Aug. 1 to Sept. 18, 2017 period for measurement stations in the $\mathrm{AB}+\mathrm{BC}$, ID+MT+OR+WA, and Northern-Canada regions. Note that there is only one measurement station (in Oregon) for the $\mathrm{ID}+\mathrm{MT}+\mathrm{OR}+\mathrm{WA}$ region.

\begin{tabular}{|c|c|c|c|c|c|c|c|c|c|}
\cline { 2 - 11 } \multicolumn{1}{c|}{} & \multicolumn{3}{c|}{ AB+BC (71 stations) } & \multicolumn{2}{c|}{ ID+MT+OR+WA (1 station in OR) } & \multicolumn{2}{c|}{ Northern-Canada (10 stations) } \\
\hline Model & RAQDPS & $\begin{array}{c}\text { FW- } \\
\text { Ops }\end{array}$ & $\begin{array}{c}\text { FW- } \\
\text { CFFEPS }\end{array}$ & RAQDPS & FW-Ops & FW-CFFEPS & RAQDPS & $\begin{array}{c}\text { FW- } \\
\text { Ops }\end{array}$ & FW-CFFEPS \\
\hline count & \multicolumn{3}{|c|}{3477} & \multicolumn{3}{|c|}{46} & \multicolumn{3}{c|}{342} \\
\hline $\bar{O}$ & \multicolumn{3}{|c|}{14} & \multicolumn{3}{|c|}{17} & \multicolumn{3}{c|}{10} \\
\hline $\bar{M}$ & 20 & 22 & 20 & 41 & 47 & 42 & 15 & 15 & 15 \\
\hline $\mathrm{MB}$ & 7 & 8 & 7 & 24 & 29 & 24 & 5 & 5 & 5 \\
\hline $\mathrm{R}$ & 0.59 & 0.58 & 0.59 & 0.53 & 0.57 & 0.54 & 0.44 & 0.44 & 0.45 \\
\hline $\mathrm{RMSE}$ & 15 & 18 & 15 & 30 & 37 & 31 & 11 & 11 & 11 \\
\hline
\end{tabular}

Table S9. $\mathrm{NO}_{2}$ categorical scores based on a threshold of $30 \mathrm{ppbv}$ for the Aug. 1 to Sept. 18, 2017 period for measurement stations in the $\mathrm{AB}+\mathrm{BC}, \mathrm{ID}+\mathrm{MT}+\mathrm{OR}+\mathrm{WA}$, and Northern-Canada regions. Note that there is only one measurement station (in Oregon) for the ID+MT+OR+WA region.

\begin{tabular}{|l|r|r|r|r|r|r|r|r|r|}
\cline { 2 - 10 } \multicolumn{1}{c|}{} & \multicolumn{3}{c|}{ AB+BC } & \multicolumn{2}{c|}{ ID+MT+OR+WA (1 station in OR) } & \multicolumn{3}{c|}{ Northern-Canada } \\
\hline Model & RAQDPS & $\begin{array}{l}\text { FW- } \\
\text { Ops }\end{array}$ & $\begin{array}{l}\text { FW- } \\
\text { CFFEPS }\end{array}$ & RAQDPS & $\begin{array}{l}\text { FW- } \\
\text { Ops }\end{array}$ & FW-CFFEPS & RAQDPS & $\begin{array}{l}\text { FW- } \\
\text { Ops }\end{array}$ & $\begin{array}{l}\text { FW- } \\
\text { CFFEPS }\end{array}$ \\
\hline POD & $47 \%$ & $46 \%$ & $47 \%$ & $89 \%$ & $89 \%$ & $89 \%$ & $7 \%$ & $7 \%$ & $12 \%$ \\
\hline FAR & $91 \%$ & $92 \%$ & $91 \%$ & $69 \%$ & $73 \%$ & $70 \%$ & $98 \%$ & $98 \%$ & $97 \%$ \\
\hline CSI & $8 \%$ & $7 \%$ & $8 \%$ & $30 \%$ & $26 \%$ & $29 \%$ & $1 \%$ & $1 \%$ & $3 \%$ \\
\hline
\end{tabular}


Table S10. Model performance statistics for daily maximum PM2.5 ( $\mu \mathrm{g} \mathrm{m-3),} \mathrm{O3} \mathrm{(ppbv),} \mathrm{and} \mathrm{NO2} \mathrm{(ppbv)} \mathrm{for} \mathrm{stations}$ and days where observed daily maximum $P M_{2.5}$ was greater than $50 \mu \mathrm{g} \mathrm{m}^{-3}$ during the high fire activity period of Aug. 1 to Sept. 18, 2017. Only stations within the three western regions of interest have been pooled.

\begin{tabular}{|c|c|c|c|c|c|c|c|c|c|}
\hline Species & \multicolumn{3}{|c|}{$\mathbf{P M}_{2.5}$} & \multicolumn{3}{|c|}{$\mathrm{O}_{3}$} & \multicolumn{3}{|c|}{$\mathrm{NO}_{2}$} \\
\hline Stations & \multicolumn{3}{|c|}{$\begin{array}{c}160 \\
(\mathrm{AB}+\mathrm{BC}: 72, \\
\mathrm{WA}+\mathrm{OR}+\mathrm{ID}+\mathrm{MT}: 88)\end{array}$} & \multicolumn{3}{|c|}{$\begin{array}{c}67 \\
\text { (AB+BC:58, } \\
\text { WA+OR+ID+MT:9) }\end{array}$} & \multicolumn{3}{|c|}{$\begin{array}{c}62 \\
(\mathrm{AB}+\mathrm{BC}: 61 \\
\mathrm{WA}+\mathrm{OR}+\mathrm{ID}+\mathrm{MT}: 1)\end{array}$} \\
\hline Model & RAQDPS & FWops & FWcffeps & RAQDPS & FWops & FWcffeps & RAQDPS & FWops & FWcffeps \\
\hline Count & \multicolumn{3}{|c|}{1772} & \multicolumn{3}{|c|}{590} & \multicolumn{3}{|c|}{519} \\
\hline$\overline{\mathrm{O}}$ & \multicolumn{3}{|c|}{95} & \multicolumn{3}{|c|}{52} & \multicolumn{3}{|c|}{19} \\
\hline$\overline{\mathrm{M}}$ & 20 & 289 & 146 & 63 & 151 & 74 & 23 & 30 & 23 \\
\hline MB & -76 & 194 & 50 & 12 & 100 & 22 & 4 & 11 & 4 \\
\hline $\mathrm{R}$ & -0.04 & 0.36 & 0.46 & 0.45 & 0.04 & 0.42 & 0.59 & 0.51 & 0.58 \\
\hline RMSE & 91 & 533 & 179 & 27 & 156 & 36 & 18 & 30 & 19 \\
\hline
\end{tabular}




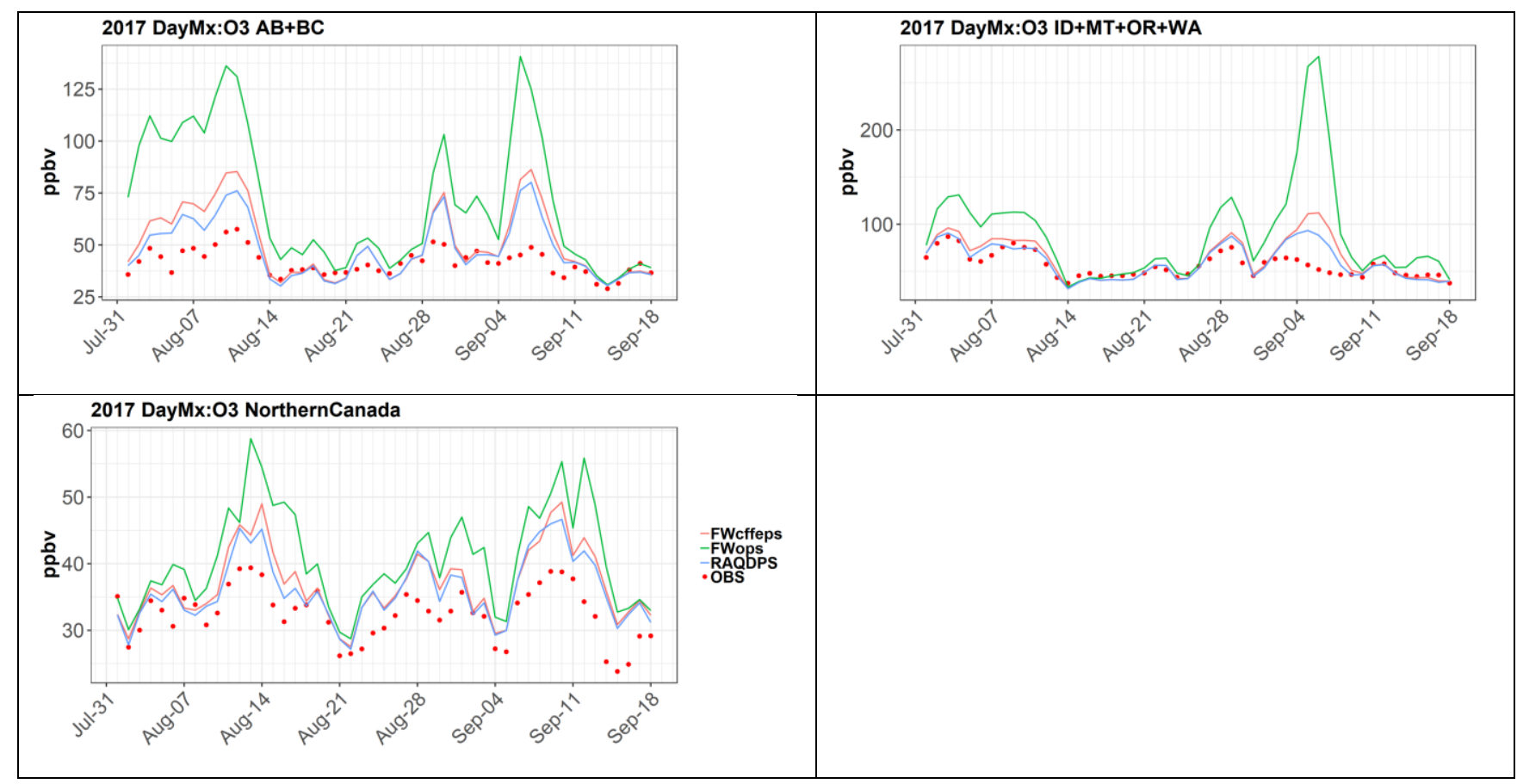

Figure S1. Time series of mean daily maximum $\mathrm{O}_{3}$ volume mixing ratio (ppbv) from Aug. 1 to Sept. 18,2017 for the three forecast models and surface measurements $(\mathrm{OBS})$ averaged across measurement stations in the $\mathrm{AB}+\mathrm{BC}, \mathrm{ID}+\mathrm{MT}+\mathrm{OR}+\mathrm{WA}$, and Northern-Canada regions.

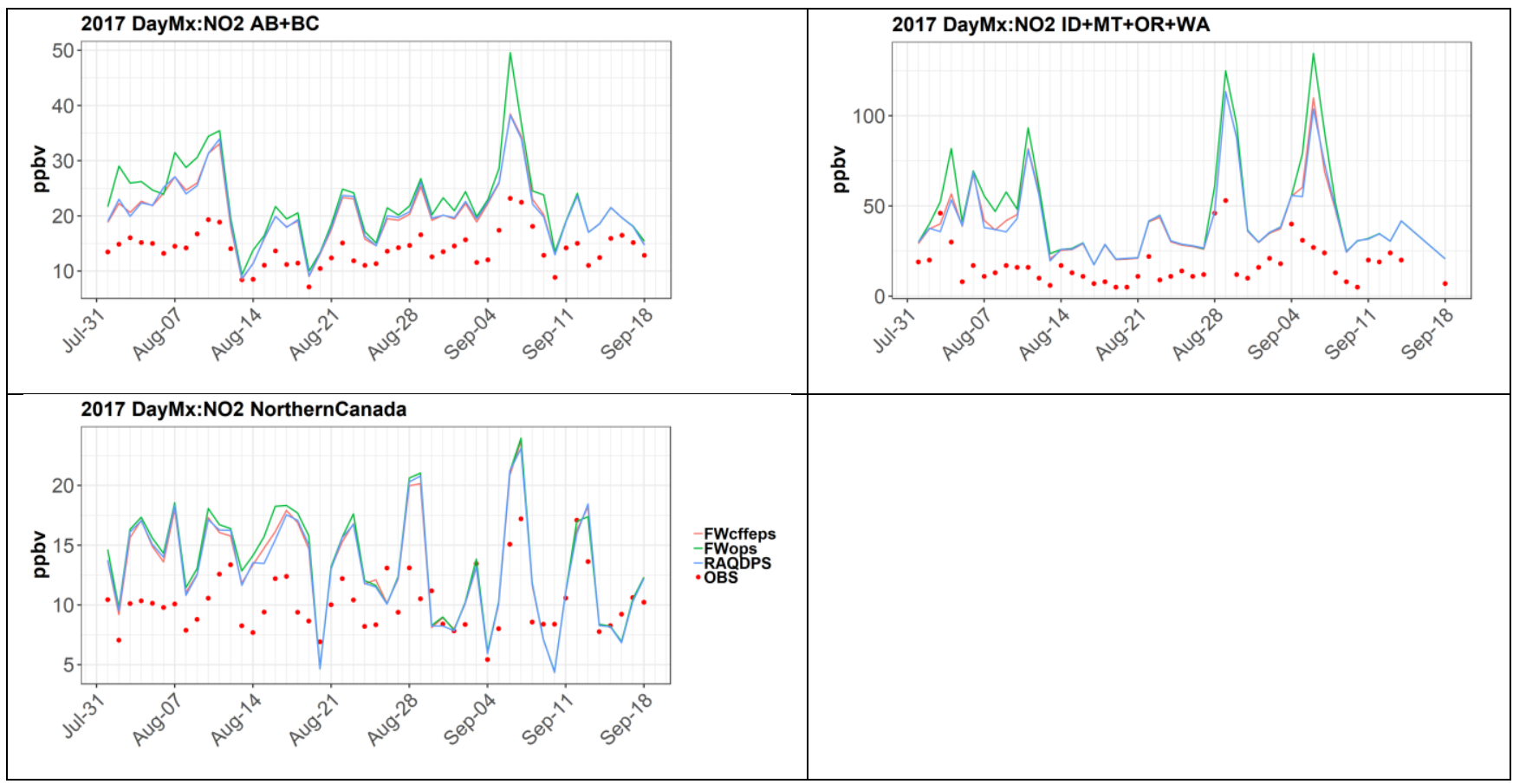

Figure S2. Time series of mean daily maximum $\mathrm{NO}_{2}$ volume mixing ratio (ppbv) from Aug. 1 to Sept. 18, 2017 the three forecast models and surface measurements (OBS) averaged across measurement stations in AB+BC, ID+MT+OR+WA and Northern-Canada regions 


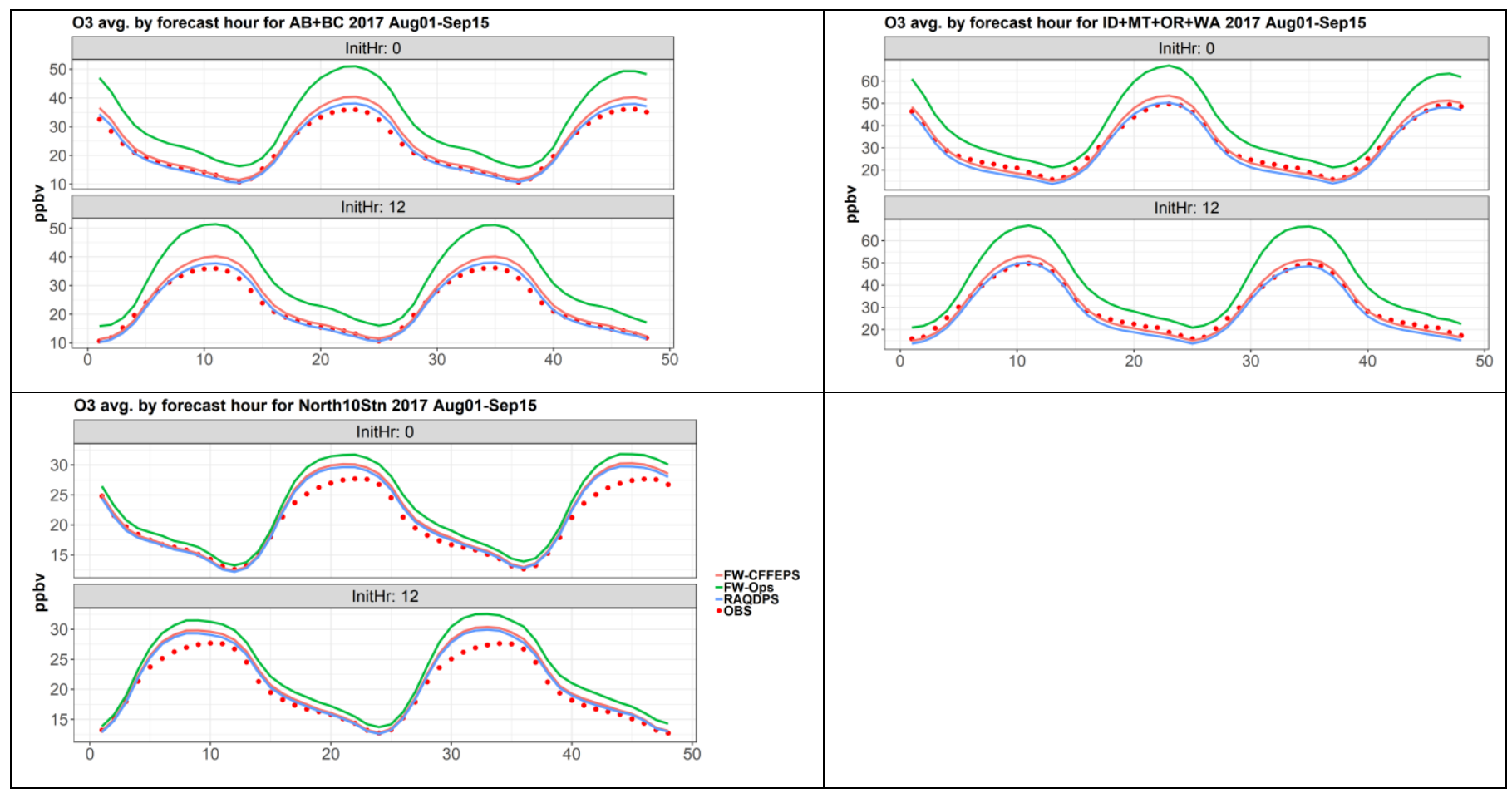

Figure S3. Mean $\mathrm{O}_{3}$ volume mixing ratio (ppbv) by forecast hour (f00-f48) for the period from Aug. 1 to Sept. 16, 2017 for the three forecast models and surface measurements (OBS) for measurement stations in the $A B+B C, I D+M T+O R+W A$, and Northern-Canada regions.

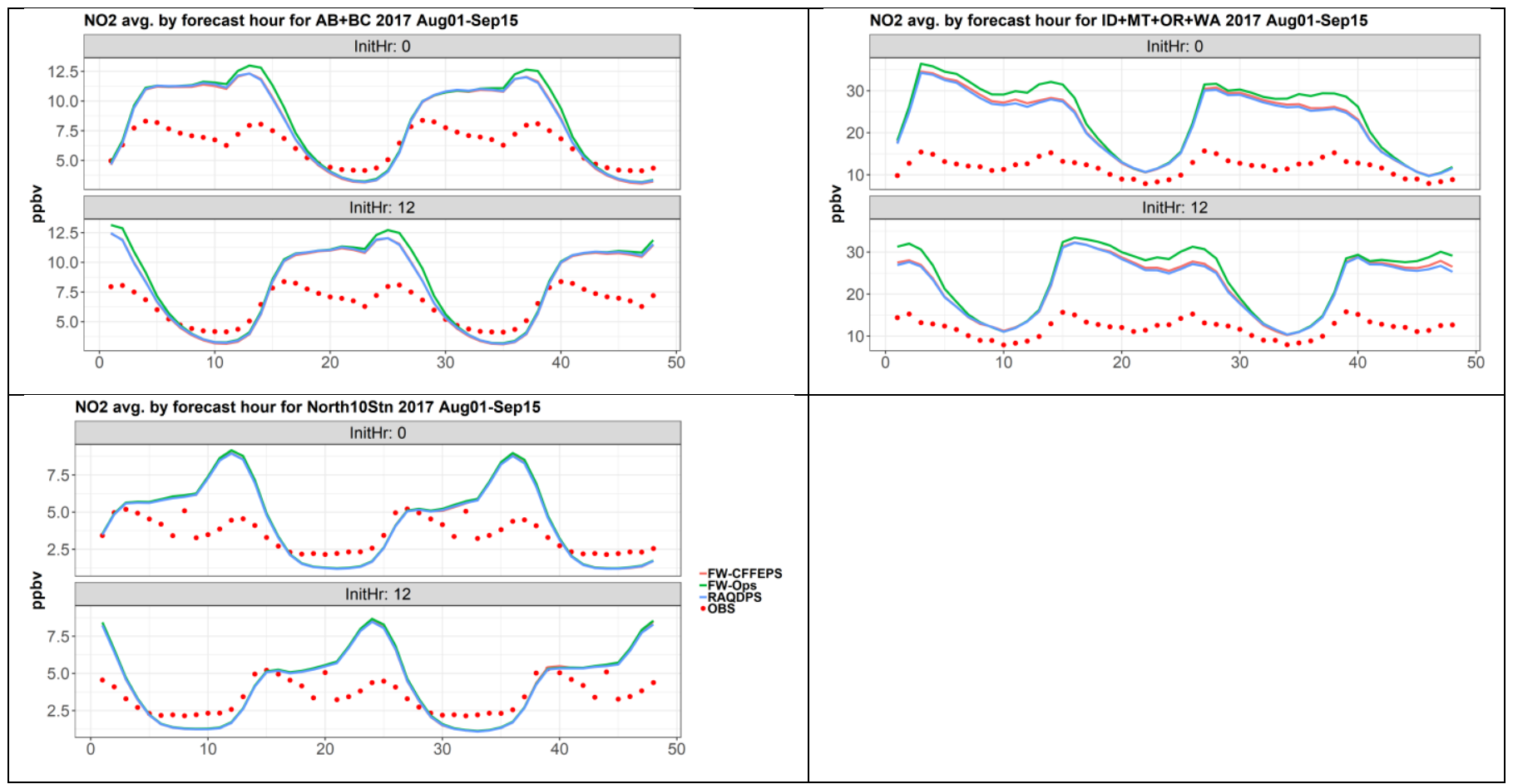

5 Figure S4. Mean $\mathrm{NO}_{2}$ volume mxing ratio (ppbv) by forecast hour (f00-f48) from Aug. 1 to Sept. 16,2017 for the three forecast models and surface measurements (OBS) for measurement stations in the $A B+B C, I D+M T+O R+W A$ and Northern-Canada regions. 


\section{S3. Model Forecast Evaluation for the 2018 Fire Season}

Similar to the model forecast evaluation for the 2017 fire season presented in Section 3.1, model outputs from FireWork-CFFEPS and FireWork-Ops were analysed and benchmarked against RAQDPS for the 2018 season. FireWork-CFFEPS was run in hindcast mode with the same forecast configuration as FireWork-Ops for three months (July to August) in 2018 that covered periods of

5 high wildfire activity in Canada.

2018 was an extreme year for fire activity in Canada. Most fires occurred in BC in August but there was some activity in eastern Canada earlier in the summer. Figure S5 shows the Canada-wide weekly burned area starting in May 1, 2018 compared to the 10year average. The last three weeks of August 2018 stand out for higher-than-average fire activity.

The $\mathrm{PM}_{2.5}$ contribution from fire emissions (fire- $\mathrm{PM}_{2.5}$ ), both primary and secondary, can be derived from the difference in model output between RAQDPS and FireWork during the same time period. Figure S6 shows monthly mean forecast surface fire-PM 2.5 concentrations from FireWork-CFFEPS and FireWork-Ops for the 2018 fire season, with the contribution from fire-PM $\mathrm{PM}_{2.5}$ dominating near areas of fire activity. Similar to the analysis for the 2017 fire season (Figure 7), there are generally lower surface concentrations near areas of hotspot sources but overall larger spatial distributions of lower level $\mathrm{PM}_{2.5}$ concentrations for FireWork-CFFEPS compared to FireWork-Ops.

15 Daily maximum hourly model forecast surface concentrations for $\mathrm{PM}_{2.5}, \mathrm{O}_{3}$, and $\mathrm{NO}_{2}$ were analysed against available hourly surface measurements from the Canadian NAPS network and the U.S. AQS network. The number of available measurement stations and their distribution across the model domain are indicated in Figure S7. Model results are paired by forecast time and by the grid cell enclosing the station location. Only stations with greater than $>75 \%$ measurement completeness were included. Most of the measurement stations are located in urban and suburban areas with high population density. Also, most of the NAPS network stations have co-located measurements for all three pollutants whereas there are comparatively fewer stations in the U.S. AQS network that measure $\mathrm{NO}_{2}$.

Model forecast performance statistics and categorical scores were calculated for stations across the four large geographic regions (WCAN, ECAN, WUSA, EUSA) shown in Figure 1 and separately for stations within the two westernmost Canadian provinces $(\mathrm{BC}, \mathrm{AB})$ and two western U.S. states (WA, MT) that were strongly impacted by fire emissions during the fire season. Table S11 provides a comparison of forecast statistics for FireWork-CFFEPS and FireWork-Ops with the RAQDPS. Table S12 provides a similar comparison of categorical scores for the same concentration threshold levels that were used in the 2017 evaluation analysis: $\mathrm{PM}_{2.5}$ threshold of $30 \mu \mathrm{g} \mathrm{m}^{-3}, \mathrm{O}_{3}$ threshold of $65 \mathrm{ppbv}$, and $\mathrm{NO}_{2}$ threshold of $30 \mathrm{ppbv}$. Similar to the results shown in Section 3.1 for 2017, FireWork also outperforms the RAQDPS for $\mathrm{PM}_{2.5}$ and FireWork-CFFEPS outperforms FireWork-Ops in 2018. Figure $\mathrm{S} 8$ and Figure $\mathrm{S} 9$ show time series of mean daily maximum $\mathrm{PM}_{2.5}, \mathrm{O}_{3}$, and $\mathrm{NO}_{2}$ abundances over the three months averaged over stations within two western Canadian provinces (AB, BC) and two western U.S. states (MT, WA). The FireWork-CFFEPS time series generally reduce pollutant over-predictions associated with FireWork-Ops while at the same time capturing fire contributions to $\mathrm{PM}_{2.5}$ that are missed by the RAQDPS. The number of stations used to calculate the averages as well as selected model evaluation statistics over the three-month period are also listed within the two figures.

Model performance by forecast hour in terms of diurnal variability predicted by the three forecast systems for the stations in the two regions $(\mathrm{AB}+\mathrm{BC}$ and $\mathrm{MT}+\mathrm{WA})$ are presented in Figure S10. Similar to Figure 9, Figure S3, and Figure S4, modelled and measured surface $\mathrm{PM}_{2.5}, \mathrm{O}_{3}$ and $\mathrm{NO}_{2}$ were paired and averaged by forecast hour ( $\mathrm{f} 00$ - $\mathrm{f} 48$ ) over all stations within the region during period of high fire activity from Aug. 13 to Aug. 26 2018. As with the evaluation for 2017, there are improvements to $\mathrm{O}_{3}$ hourly 
variability with FireWork-CFFEPS compared to FireWork-Ops, and minimal changes to $\mathrm{NO}_{2}$ concentrations. However, unlike the 2017 evaluation, the hourly forecast performance for $\mathrm{PM}_{2.5}$ is under-predicted with FireWork-CFFEPS, and the concentration ranges were better represented with FireWork-Ops. Upon further analysis, this is due to effects of averaging over periods of underprediction in both FireWork systems (Aug. 13-20 2018), together with periods of large over-predictions in the FireWork-Ops system (Aug. 20-26 2017). The compensation of forecast $\mathrm{PM}_{2.5}$ errors in the FireWork-Ops system resulted in the overall better diurnal average compared to FireWork-CFFEPS. This can be observed from examples of station specific hourly $\mathrm{PM}_{2.5}$ concentrations time series comparisons from $\mathrm{AB}$ and $\mathrm{BC}$ in Figure $\mathrm{S} 11$.

Similar to Section 3.1.5, fire-PM 2.5 VCD fields $\left(\mathrm{g} \mathrm{m}^{-2}\right)$ from the FireWork-CFFEPS and FireWork-Ops forecasts were subjectively compared against NASA's VIIR-true-colour image for a case study. Figure S12 shows the 24-hour forecast fire-PM 2.5 VCD field

10 from the FireWork-Ops and FireWork-CFFEPS simulations from the Aug. 2212 UTC simulation, valid at Aug. 23 12 UTC. These fields are compared against a VIIRS true colour satellite image for Aug. 23, 2018. A visual comparison reveals lower $\mathrm{PM}_{2.5}$ VCD near fire hotspots, but in general a more widespread spatial distribution for FireWork-CFFEPS compared to FireWork-Ops. Figure $\mathrm{S} 13$ shows a quantitative comparison of hourly surface $\mathrm{PM}_{2.5}$ concentration time series over the same period (Aug. 22-25) from selected stations across Canada. Forecast concentrations were well represented from FireWork-CFFEPS for stations in the west,

15 near sources of fire hotspots. However, surface $\mathrm{PM}_{2.5}$ concentrations were generally under-predicted for stations further downwind of the fire hotspots in Ontario and Quebec, though with FireWork-CFFEPS showing slightly higher forecast concentrations than FireWork-Ops.

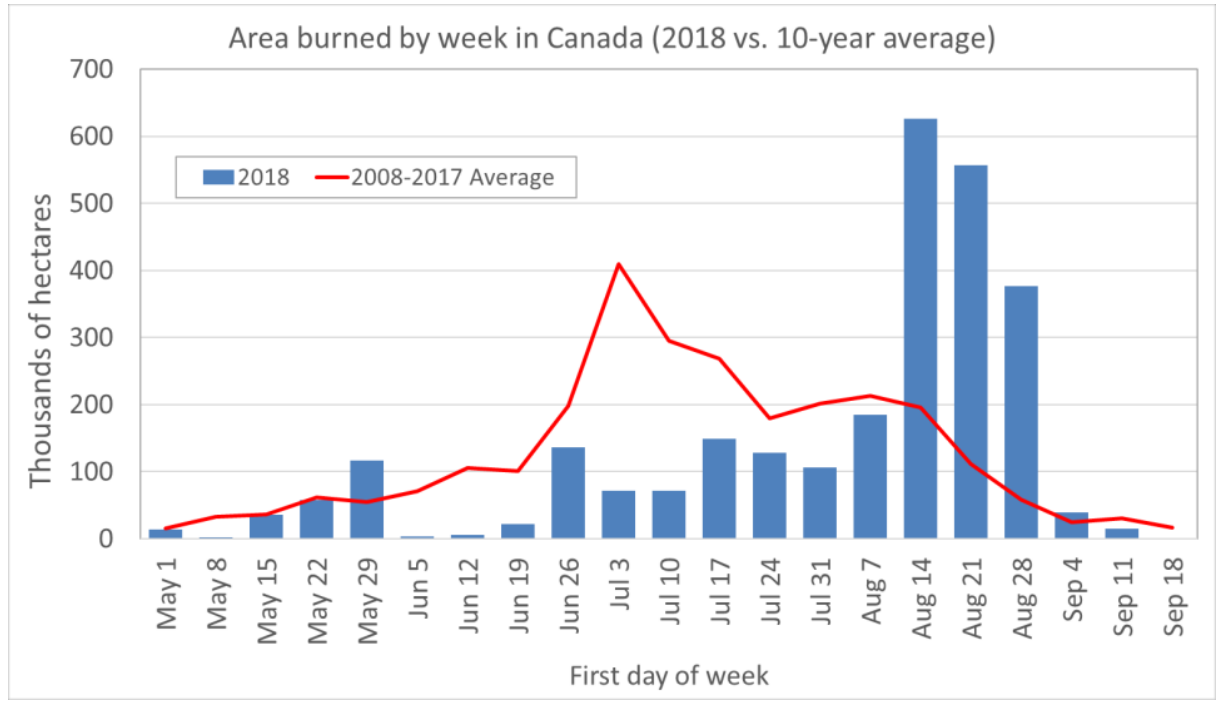

20 Figure S5. National fire burn area in Canada by week for 2018 fire season (blue vertical bars) and previous 10-year average (red line). 


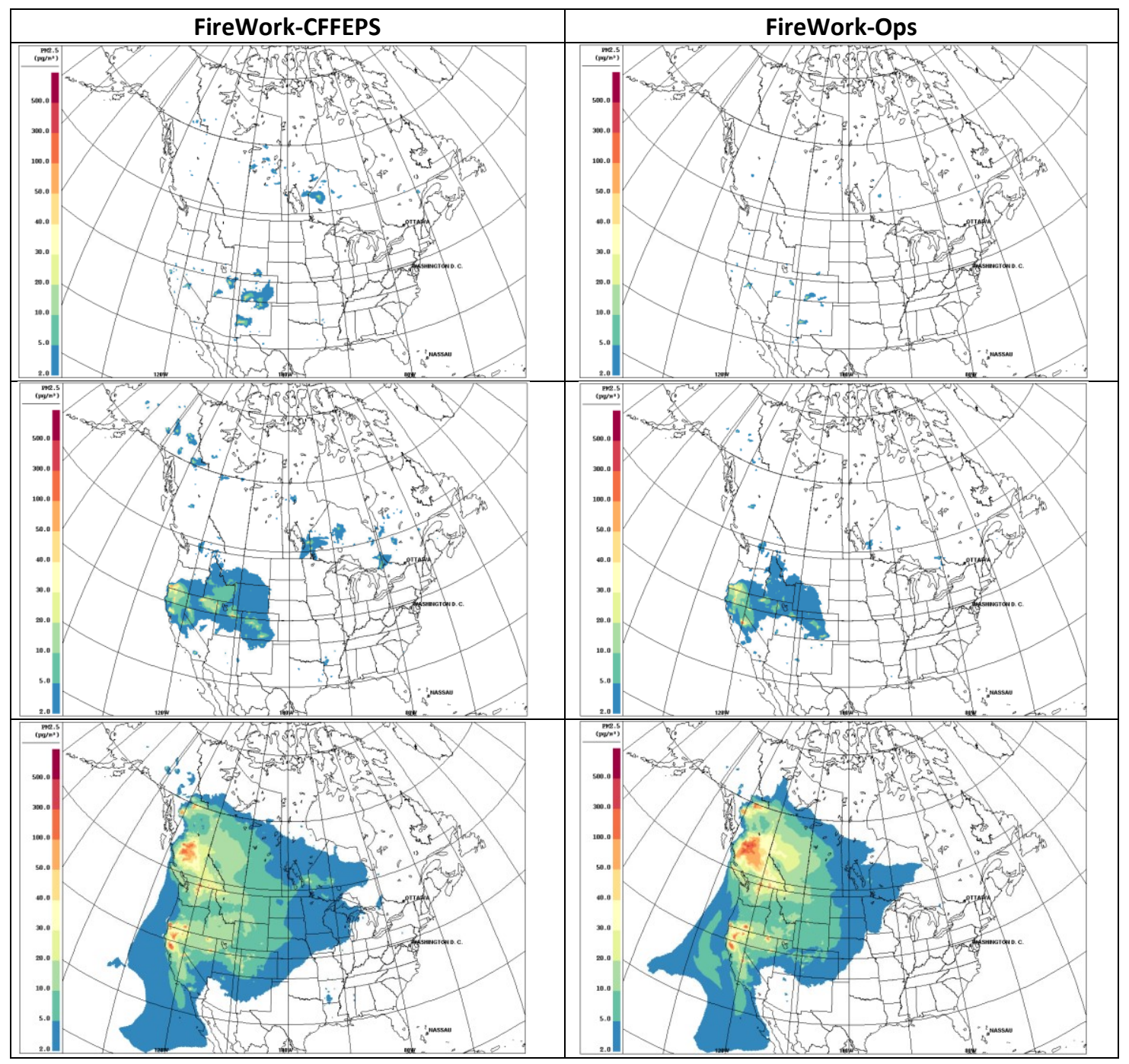

Figure S6. Mean monthly surface fire-PM 2.5 concentrations $\left(\mu \mathrm{g} \mathrm{m}^{-3}\right)$ from FireWork-CFFEPS (left) and FireWork-Ops (right) for June (top row), July (middle row), and August (bottom row) 2018. 


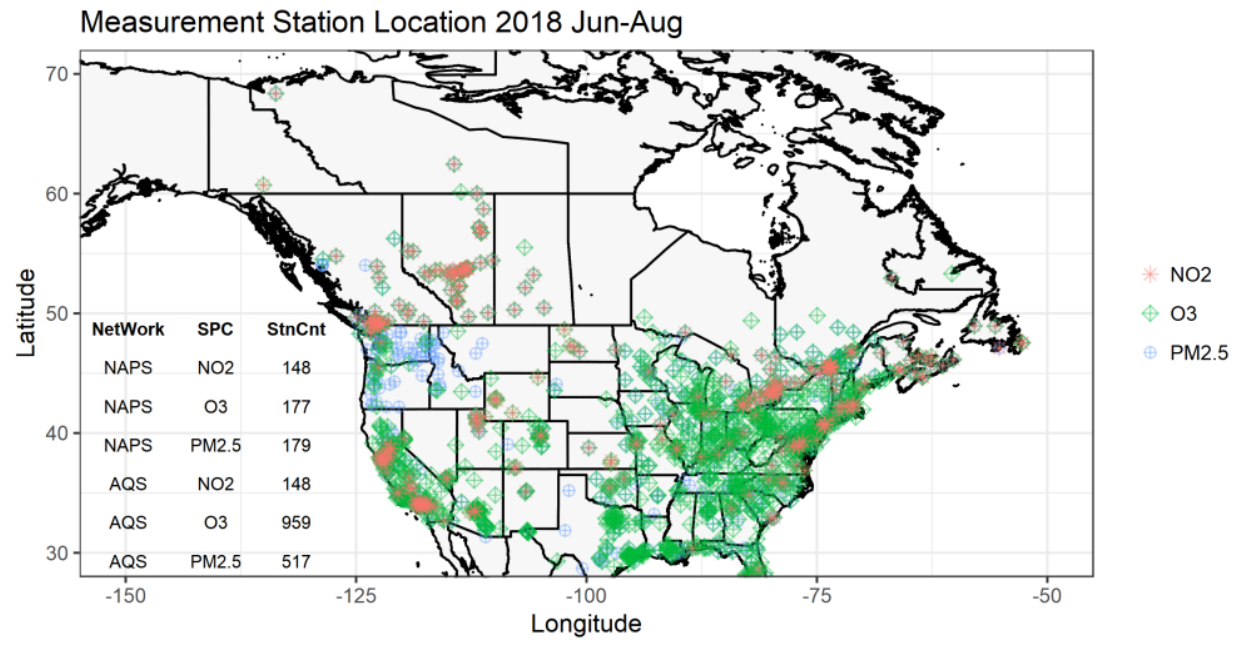

Figure S7. Locations of Canadian NAPS and U.S. AQS stations used for 2018 model evaluation with $75 \%$ measurement completeness criterion. Some stations measure more than one species. 


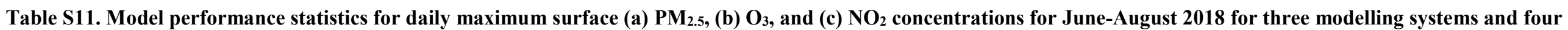
geographic regions (shown in Figure 1). Units of $\overline{\mathrm{O}}, \overline{\mathrm{M}}, \mathrm{MB}$, and $\mathrm{RMSE}$ are $\mu_{\mathrm{g}} \mathbf{m}^{-3}$ for $\mathrm{PM}_{2.5}$ and ppbv for $\mathrm{O}_{3}$ and NO $\mathrm{O}_{2}$.

\begin{tabular}{|c|c|c|c|c|c|c|c|c|c|c|c|c|}
\hline \multirow{2}{*}{$\begin{array}{r}\text { (a) } \mathbf{P M}_{2.5} \\
\text { Model }\end{array}$} & \multicolumn{3}{|c|}{ WCAN (81 stations, $n=7369$ ) } & \multicolumn{3}{|c|}{ ECAN (98 stations, $n=8870$ ) } & \multicolumn{3}{|c|}{ WUSA (198 stations, $n=17852$ ) } & \multicolumn{3}{|c|}{ EUSA (319 stations, $n=28664$ ) } \\
\hline & RAQDPS & $\begin{array}{l}\text { FW- } \\
\text { Ops }\end{array}$ & $\begin{array}{c}\text { FW- } \\
\text { CFFEPS }\end{array}$ & RAQDPS & $\begin{array}{l}\text { FW- } \\
\text { Ops }\end{array}$ & $\begin{array}{c}\text { FW- } \\
\text { CFFEPS }\end{array}$ & RAQDPS & $\begin{array}{l}\text { FW- } \\
\text { Ops }\end{array}$ & $\begin{array}{c}\text { FW- } \\
\text { CFFEPS }\end{array}$ & RAQDPS & $\begin{array}{l}\text { FW- } \\
\text { Ops }\end{array}$ & $\begin{array}{c}\text { FW- } \\
\text { CFFEPS }\end{array}$ \\
\hline$\overline{0}$ & \multicolumn{3}{|c|}{27} & \multicolumn{3}{|c|}{14} & \multicolumn{3}{|c|}{22} & \multicolumn{3}{|c|}{17} \\
\hline$\overline{\mathrm{M}}$ & 10 & 30 & 21 & 13 & 14 & 15 & 12 & 26 & 25 & 16 & 16 & 17 \\
\hline MB & -16.9 & 2.9 & -5.9 & 0.0 & 0.2 & 1.3 & -10.1 & 3.5 & 2.4 & -0.8 & -1.0 & 0.2 \\
\hline $\mathrm{R}$ & 0.16 & 0.53 & 0.64 & 0.19 & 0.27 & 0.32 & 0.10 & 0.49 & 0.50 & 0.19 & 0.20 & 0.20 \\
\hline RMSE & 45 & 78 & 35 & 13 & 13 & 13 & 30 & 56 & 47 & 13 & 13 & 13 \\
\hline
\end{tabular}

\begin{tabular}{|c|c|c|c|c|c|c|c|c|c|c|c|c|}
\hline \multirow{2}{*}{$\begin{array}{l}\text { (b) } \mathbf{O}_{3} \\
\text { Model }\end{array}$} & \multicolumn{3}{|c|}{ WCAN (76 stations, $n=6919$ ) } & \multicolumn{3}{|c|}{ ECAN (101 stations, $n=9181$ ) } & \multicolumn{3}{|c|}{ WUSA (270 stations, $n=24545$ ) } & \multicolumn{3}{|c|}{ EUSA (689 stations, $n=62559$ ) } \\
\hline & RAQDPS & $\begin{array}{l}\text { FW- } \\
\text { Ops }\end{array}$ & $\begin{array}{c}\text { FW- } \\
\text { CFFEPS }\end{array}$ & RAQDPS & $\begin{array}{l}\text { FW- } \\
\text { Ops }\end{array}$ & $\begin{array}{c}\text { FW- } \\
\text { CFFEPS }\end{array}$ & RAQDPS & $\begin{array}{l}\text { FW- } \\
\text { Ops }\end{array}$ & $\begin{array}{c}\text { FW- } \\
\text { CFFEPS }\end{array}$ & RAQDPS & FW-Ops & $\begin{array}{c}\text { FW- } \\
\text { CFFEPS }\end{array}$ \\
\hline$\overline{0}$ & \multicolumn{3}{|c|}{41} & \multicolumn{3}{|c|}{42} & \multicolumn{3}{|c|}{61} & \multicolumn{3}{|c|}{48} \\
\hline$\overline{\mathrm{M}}$ & 42 & 50 & 43 & 50 & 50 & 50 & 72 & 78 & 73 & 69 & 69 & 70 \\
\hline $\mathrm{MB}$ & 1 & 9 & 3 & 8 & 8 & 8 & 10 & 17 & 12 & 21 & 21 & 22 \\
\hline $\mathrm{R}$ & 0.69 & 0.45 & 0.68 & 0.73 & 0.73 & 0.73 & 0.65 & 0.53 & 0.65 & 0.65 & 0.66 & 0.66 \\
\hline RMSE & 13 & 29 & 14 & 15 & 16 & 16 & 22 & 34 & 23 & 27 & 27 & 27 \\
\hline
\end{tabular}

\begin{tabular}{|c|c|c|c|c|c|c|c|c|c|c|c|c|}
\hline \multirow{2}{*}{$\begin{array}{r}\text { (c) } \mathrm{NO}_{2} \\
\text { Model }\end{array}$} & \multicolumn{3}{|c|}{ WCAN (77 stations, $n=7035$ ) } & \multicolumn{3}{|c|}{ ECAN (71 stations, $n=6467$ ) } & \multicolumn{3}{|c|}{ WUSA (74 stations, $n=6743$ ) } & \multicolumn{3}{|c|}{ EUSA (74 stations, $n=6652$ ) } \\
\hline & RAQDPS & $\begin{array}{l}\text { FW- } \\
\text { Ops }\end{array}$ & $\begin{array}{c}\text { FW- } \\
\text { CFFEPS }\end{array}$ & RAQDPS & $\begin{array}{l}\text { FW- } \\
\text { Ops }\end{array}$ & $\begin{array}{c}\text { FW- } \\
\text { CFFEPS }\end{array}$ & RAQDPS & $\begin{array}{l}\text { FW- } \\
\text { Ops }\end{array}$ & $\begin{array}{c}\text { FW- } \\
\text { CFFEPS }\end{array}$ & RAQDPS & $\begin{array}{l}\text { FW- } \\
\text { Ops }\end{array}$ & $\begin{array}{l}\text { FW- } \\
\text { CFFEPS }\end{array}$ \\
\hline$\overline{\mathrm{O}}$ & \multicolumn{3}{|c|}{11} & \multicolumn{3}{|c|}{10} & \multicolumn{3}{|c|}{14} & \multicolumn{3}{|c|}{12} \\
\hline$\overline{\mathrm{M}}$ & 16 & 17 & 16 & 16 & 16 & 16 & 29 & 29 & 29 & 26 & 26 & 26 \\
\hline $\mathrm{MB}$ & 5 & 6 & 5 & 6 & 6 & 6 & 14 & 15 & 15 & 14 & 14 & 14 \\
\hline $\mathrm{R}$ & 0.59 & 0.59 & 0.60 & 0.62 & 0.63 & 0.62 & 0.61 & 0.60 & 0.61 & 0.66 & 0.66 & 0.66 \\
\hline RMSE & 12 & 13 & 12 & 13 & 13 & 13 & 22 & 23 & 22 & 21 & 21 & 21 \\
\hline
\end{tabular}




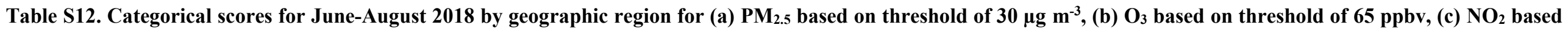
on threshold of $30 \mathrm{ppbv}$

\begin{tabular}{|c|c|c|c|c|c|c|c|c|c|c|c|c|}
\hline (a) $\mathrm{PM}_{2.5}$ & \multicolumn{3}{|c|}{ WCAN } & \multicolumn{3}{|c|}{ ECAN } & \multicolumn{3}{|c|}{ WUSA } & \multicolumn{3}{|c|}{ EUSA } \\
\hline Model & RAQDPS & $\begin{array}{l}\text { FW- } \\
\text { Ops }\end{array}$ & $\begin{array}{c}\text { FW- } \\
\text { CFFEPS }\end{array}$ & RAQDPS & $\begin{array}{l}\text { FW- } \\
\text { Ops }\end{array}$ & $\begin{array}{c}\text { FW- } \\
\text { CFFEPS }\end{array}$ & RAQDPS & $\begin{array}{l}\text { FW- } \\
\text { Ops }\end{array}$ & $\begin{array}{c}\text { FW- } \\
\text { CFFEPS }\end{array}$ & RAQDPS & $\begin{array}{l}\text { FW- } \\
\text { Ops }\end{array}$ & $\begin{array}{c}\text { FW- } \\
\text { CFFEPS }\end{array}$ \\
\hline POD & $2 \%$ & $46 \%$ & $42 \%$ & $1 \%$ & $2 \%$ & $4 \%$ & $3 \%$ & $41 \%$ & $44 \%$ & $3 \%$ & $2 \%$ & $3 \%$ \\
\hline FAR & $76 \%$ & $30 \%$ & $26 \%$ & $100 \%$ & $99 \%$ & $98 \%$ & $85 \%$ & $50 \%$ & $49 \%$ & $96 \%$ & $96 \%$ & $96 \%$ \\
\hline CSI & $1 \%$ & $38 \%$ & $37 \%$ & $0 \%$ & $1 \%$ & $1 \%$ & $2 \%$ & $29 \%$ & $31 \%$ & $1 \%$ & $1 \%$ & $2 \%$ \\
\hline
\end{tabular}

\begin{tabular}{|c|c|c|c|c|c|c|c|c|c|c|c|c|}
\hline (a) $\mathrm{O}_{3}$ & \multicolumn{3}{|c|}{ WCAN } & \multicolumn{3}{|c|}{ ECAN } & \multicolumn{3}{|c|}{ WUSA } & \multicolumn{3}{|c|}{ EUSA } \\
\hline Model & RAQDPS & $\begin{array}{l}\text { FW- } \\
\text { Ops }\end{array}$ & $\begin{array}{c}\text { FW- } \\
\text { CFFEPS }\end{array}$ & RAQDPS & $\begin{array}{l}\text { FW- } \\
\text { Ops }\end{array}$ & $\begin{array}{c}\text { FW- } \\
\text { CFFEPS }\end{array}$ & RAQDPS & $\begin{array}{l}\text { FW- } \\
\text { Ops }\end{array}$ & $\begin{array}{c}\text { FW- } \\
\text { CFFEPS }\end{array}$ & RAQDPS & $\begin{array}{l}\text { FW- } \\
\text { Ops }\end{array}$ & $\begin{array}{c}\text { FW- } \\
\text { CFFEPS }\end{array}$ \\
\hline POD & $31 \%$ & $48 \%$ & $39 \%$ & $72 \%$ & $72 \%$ & $73 \%$ & $54 \%$ & $62 \%$ & $58 \%$ & $81 \%$ & $81 \%$ & $81 \%$ \\
\hline FAR & $82 \%$ & $91 \%$ & $82 \%$ & $87 \%$ & $87 \%$ & $87 \%$ & $51 \%$ & $56 \%$ & $52 \%$ & $87 \%$ & $87 \%$ & $87 \%$ \\
\hline CSI & $13 \%$ & $8 \%$ & $14 \%$ & $12 \%$ & $12 \%$ & $12 \%$ & $35 \%$ & $35 \%$ & $35 \%$ & $13 \%$ & $13 \%$ & $13 \%$ \\
\hline
\end{tabular}

\begin{tabular}{|c|c|c|c|c|c|c|c|c|c|c|c|c|}
\hline (a) $\mathrm{NO}_{2}$ & \multicolumn{3}{|c|}{ WCAN } & \multicolumn{3}{|c|}{ ECAN } & \multicolumn{3}{|c|}{ WUSA } & \multicolumn{3}{|c|}{ EUSA } \\
\hline Model & RAQDPS & $\begin{array}{l}\text { FW- } \\
\text { Ops }\end{array}$ & $\begin{array}{c}\text { FW- } \\
\text { CFFEPS }\end{array}$ & RAQDPS & $\begin{array}{l}\text { FW- } \\
\text { Ops }\end{array}$ & $\begin{array}{c}\text { FW- } \\
\text { CFFEPS }\end{array}$ & RAQDPS & $\begin{array}{l}\text { FW- } \\
\text { Ops }\end{array}$ & $\begin{array}{c}\text { FW- } \\
\text { CFFEPS }\end{array}$ & RAQDPS & $\begin{array}{l}\text { FW- } \\
\text { Ops }\end{array}$ & $\begin{array}{c}\text { FW- } \\
\text { CFFEPS }\end{array}$ \\
\hline POD & $41 \%$ & $41 \%$ & $42 \%$ & $24 \%$ & $25 \%$ & $24 \%$ & $76 \%$ & $76 \%$ & $76 \%$ & $53 \%$ & $54 \%$ & $54 \%$ \\
\hline FAR & $95 \%$ & $95 \%$ & $95 \%$ & $98 \%$ & $98 \%$ & $98 \%$ & $93 \%$ & $93 \%$ & $93 \%$ & $95 \%$ & $95 \%$ & $95 \%$ \\
\hline CSI & $5 \%$ & $5 \%$ & $5 \%$ & $2 \%$ & $2 \%$ & $2 \%$ & $6 \%$ & $6 \%$ & $6 \%$ & $5 \%$ & $5 \%$ & $5 \%$ \\
\hline
\end{tabular}




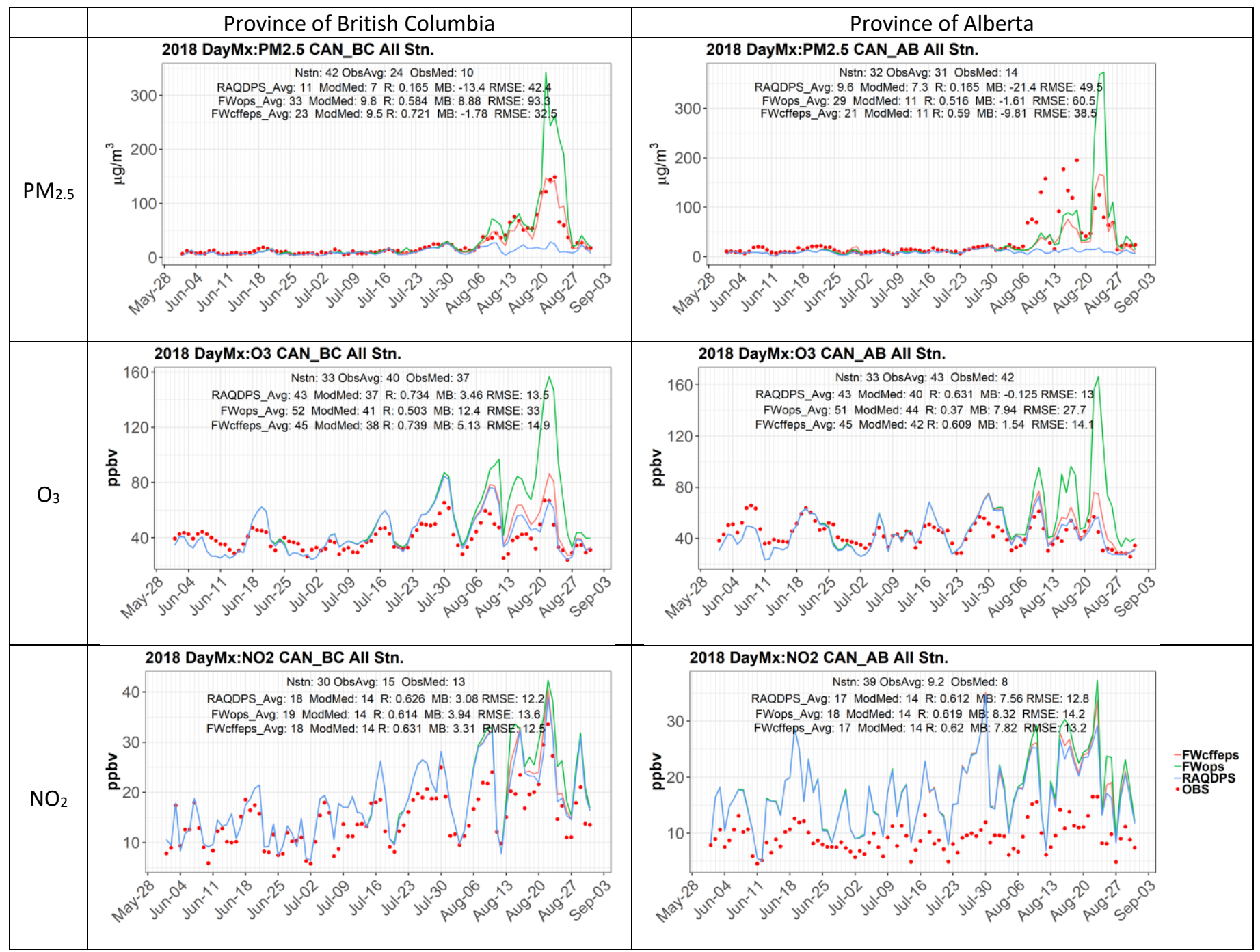

Figure S8. Time series of mean daily maximum $\mathrm{PM}_{2.5}, \mathrm{O}_{3}$, and $\mathrm{NO}_{2}$ abundances for $\mathrm{BC}$ and Alberta in Canada from JuneAug. 2018 for forecasts by the RAQDPS (blue lines), FireWork-Ops (green lines), and FireWork-CFFEPS (red lines). The number of stations within each province and values of some model evaluation statistics for the three-month period are also 5 listed within each panel, where Nstn is the number of measurement stations used in the calculation, ObsAvg and ObsMed are measurement average and median concentrations, respectively, RAQDPS_Avg, FWops_Avg, and FWcffeps_Avg and the ModMed on the same line are average and median forecast concentrations from the RAQDPS, FireWork-Ops, and FireWork-CFFEPS systems, respectively, MB is mean bias, and RMSE is root mean square error. 


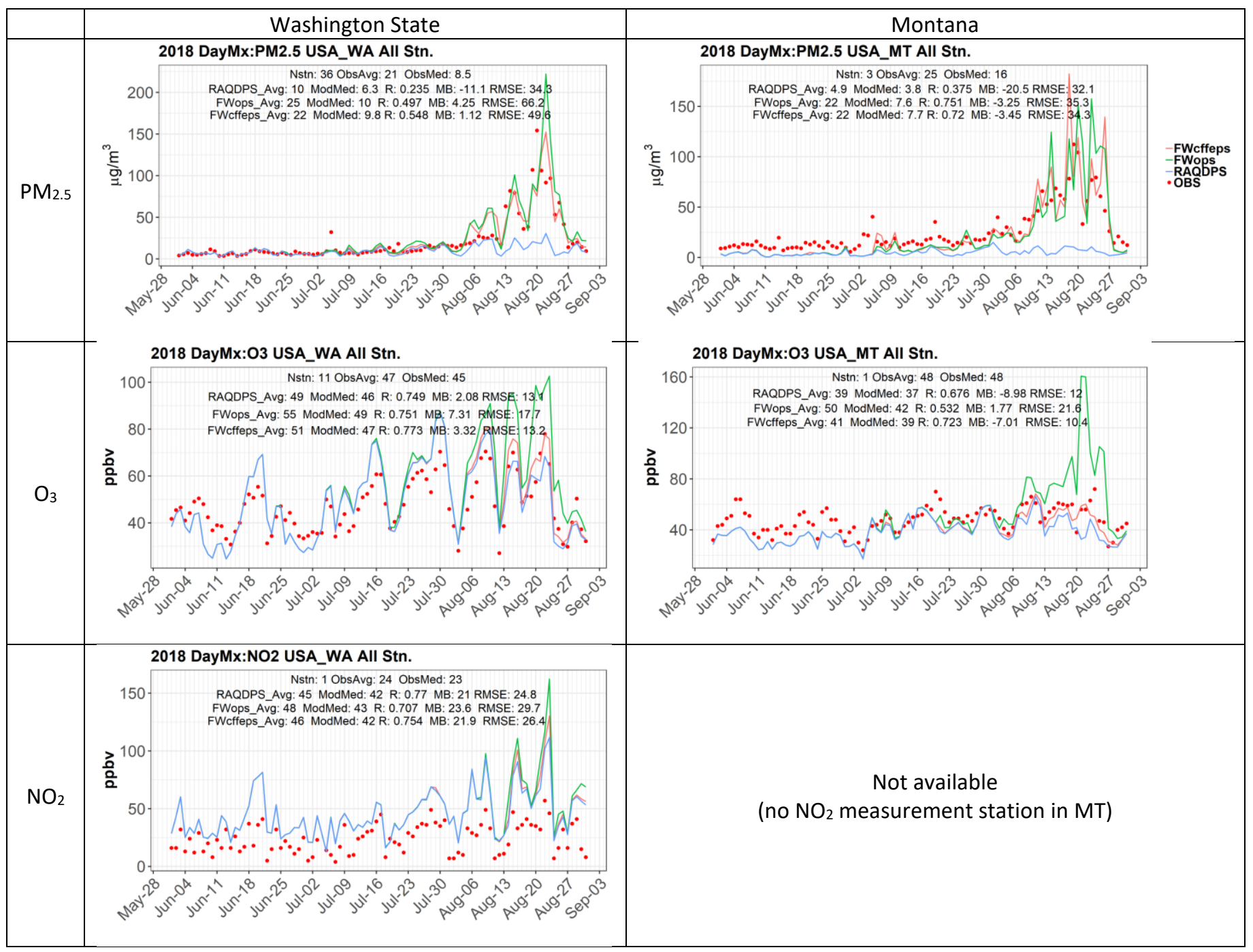

Figure S9. Same as Figure S8 but for WA and MT states in the U.S. 


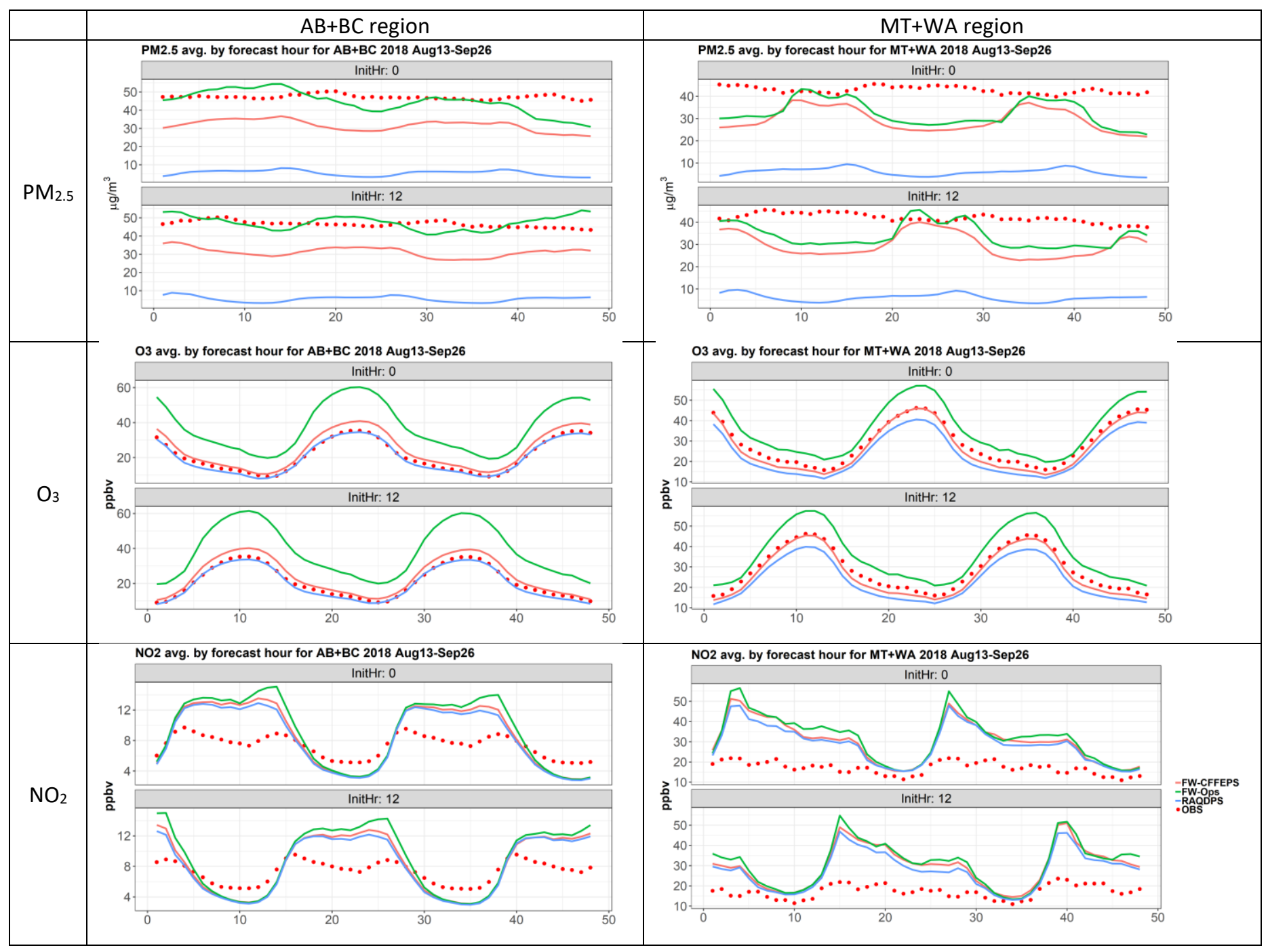

Figure S10. Mean $\mathrm{PM}_{2.5}$ concentration (top), $\mathrm{O}_{3}$ mixing ratio (middle) and $\mathrm{NO}_{2}$ mixing ratio (bottom) by forecast hour (f00f48) for the period from Aug. 13 to Aug. 26, 2018 for the three forecast models and surface measurements (OBS) for measurement stations in the $\mathrm{AB}+\mathrm{BC}$, and $\mathrm{MT}+\mathrm{WA}$ regions. Note there is only one $\mathrm{NO}_{2}$ measurement station in $\mathrm{WA}$ for the MT+WA region. 


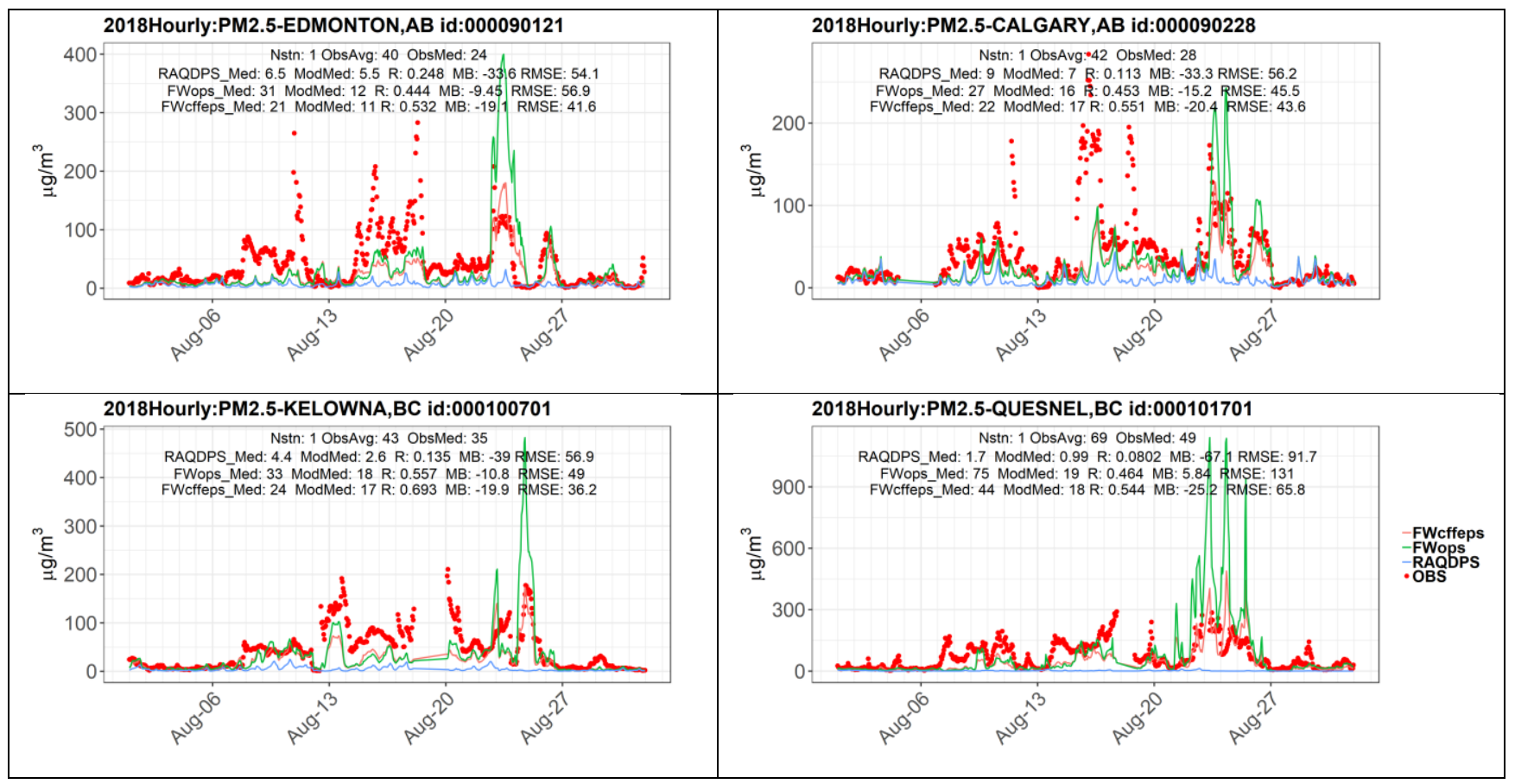

Figure S11. Hourly time series of PM2.5 concentrations for Edmonton (lat./lon.: 53.54823/-113.3681) , Calgary (lat./lon.: 51.04701/- 114.0756 ) in AB, and Kelowna (lat./lon.: 49.86234/ -119.4774), Quesnel (lat./lon.: 52.98169 / -122.4932) in BC for Aug. 1-31 2018 for forecasts by the RAQDPS (blue lines), FireWork-Ops (green lines), and FireWork-CFFEPS (red lines). Model evaluation statistics for the period are listed within each panel similar to Figure S8. 


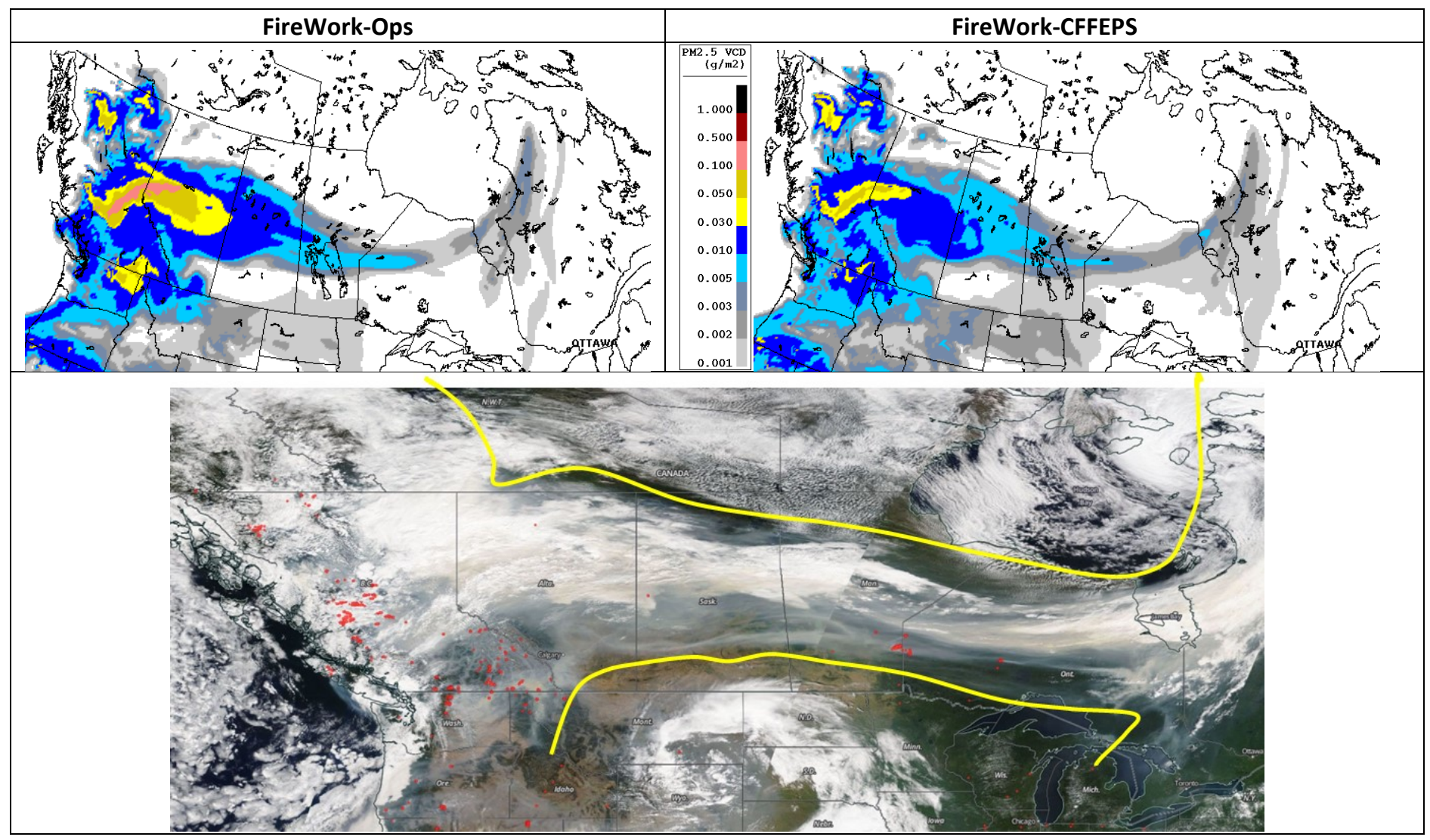

Figure S12. Fire-PM $M_{2.5}$ VCD fields $\left(\mathrm{g} \mathrm{m}^{-2}\right)$ forecast by FireWork-Ops (top left) and FireWork-CFFEPS (top right) from the Aug. 22, 201812 UTC forecast run valid for August 23, 201812 UTC, and (bottom) VIIRS true colour satellite image for August 23, 2018 with yellow lines superimposed to aid comparison. Fire hotspots are represented as red dots. VIIRS image source: NASA https://worldview.earthdata.nasa.gov 


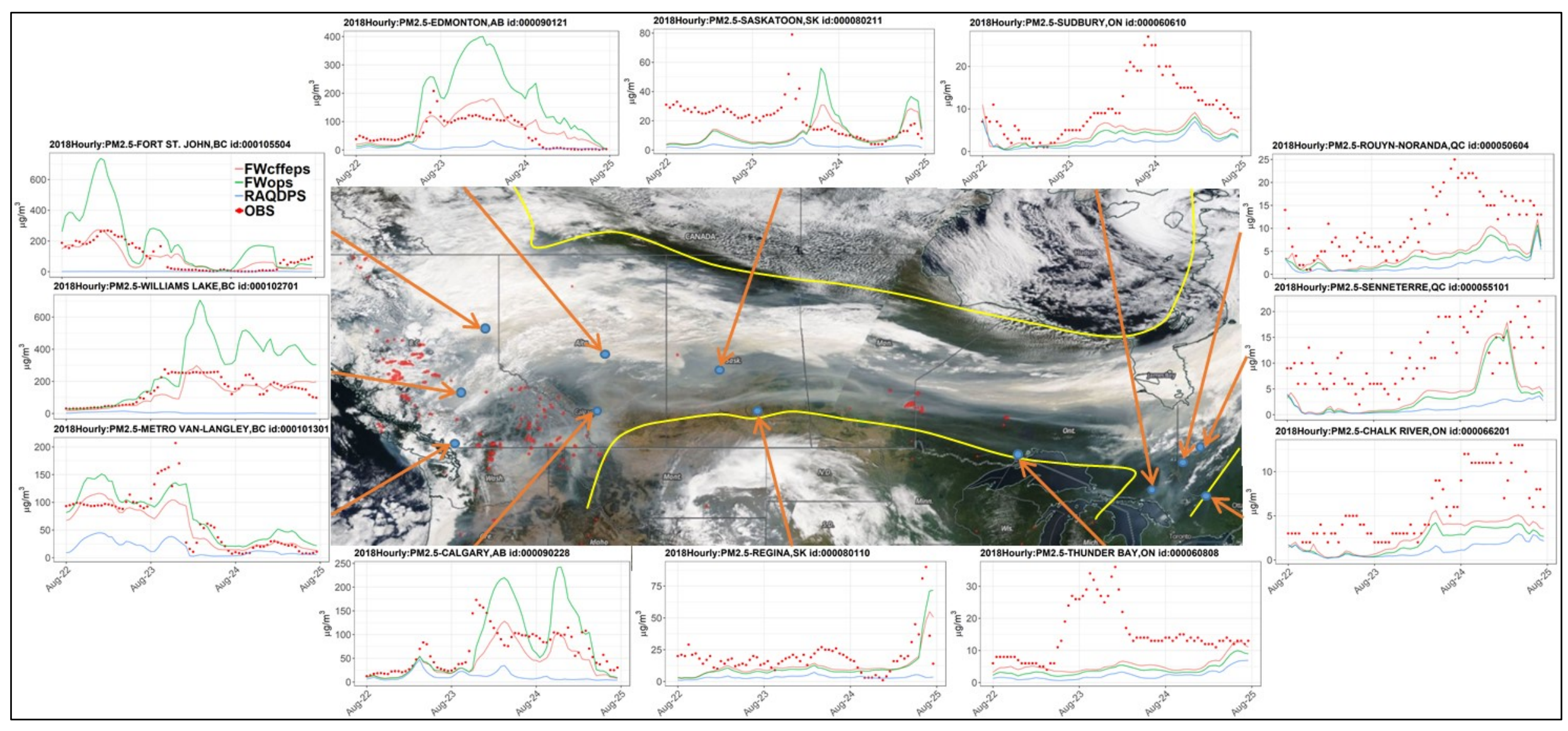

Figure S13. Time series of 2018 hourly surface PM2.5 concentration from three model simulations and measurements (OBS) for selected stations for Aug. 22-25, 2018, and (centre) VIIRS true colour satellite image for August 23, 2018 with yellow lines superimposed to aid comparison. RAQDPS forecasts are shown with blue lines, FireWorkOps forecasts with green lines, and FireWork-CFFEPS forecasts with orange lines in the inset time series plots. Station locations are represented by blue dots and fire hotspots are represented in red dots superimposed on the satellite image. VIIRS image source: NASA https://worldview.earthdata.nasa.gov. 